\title{
THE ORNAMENTAL FISH SPECIES IN THE RIVER BHIMA (EASTERN
}

\section{PART). MAHARASHTRA (INDIA)}

\section{Tejaswini P Jagtap ${ }^{1}$, Panditrao B Jagtap 2}

1.R. R. Shinde Jr. College. Hadapsar. Pune., 2.S M Joshi College Hadapsar.Pune. Email : tpjagtap2008@gmail.com

\section{Abstract}

A collection of species of ornamental fishes was made from the Eastern part of Bhima river in Maharashtra. The study was carried out during the year 2011-2012. The cyprinids dominated the list followed by loaches. Most of the ornamental fishes were collected from running water and bandhs. The weed infested bandhs are excellent habitats for varieties of ornamental fishes. The study also revealed that large scale exploitation of certain species caused drastic depletion of their stock. Application of pesticides in the agricultural land and industrial pollutants in the river flow also adversely affect the habitats of ornamental fishes.

\section{Key Words:}

Bhima river, Ornmental fishes, cyprinids

\section{Introduction}

The Western Ghats is one of the world"s most heavily populated Biodiversity Hotspots providing for and supporting 400million people through water for drinking, transport, irrigation, and hydroelectric power, together with food and resources to sustain livelihoods.[Molar et. al. 2011]. Bhima river basin contributes on large in the biodiversity of fish fauna in Maharashtra and India.

Ornamental or aquarium fishes have gained considerable importance in recent years. However, most emphasis is given to the marine ornamental fishes. Potentiality of the freshwater as a rich source of such fish fauna is yet to be recognized. Western ghats region of India is one of the richest zones of fish biodiversity. At least 50 species of ornamental fish are known from the Bhima river drainage system [Biswas, 1996]. But surprisingly so far there is no systematic account of ornamental fishes from this part of the country. 
The demand of ornamental fishes is increasing remarkably due to their important role in the world trade for fish and fishery production [Nagesh et. al.2004, Sarma et. al.2004]. A few indigenous ornamental fish species are popular among the native people of coastal West Bengal as well as to the aquarium lovers of different countries. Singapore is considered to be a major supplier of ornamental fishes in the international market [Rajan and $\mathrm{N}$. Karpagam2004]. Singapore exports about US\$80 million of ornamental fishes annually [Jameson and Sonthanam1994]. The export of ornamental fishes from India is worth only US\$0.2 mil-lion, which is not sufficient with regard to the rising demand of these beautiful colored species in the world ornamental fish market. This may be attributed to the lack of involvement of technical people in ornamental fish farming [Rajan and N. Karpagam2004]. Ninety five per cent of our ornamental fish export is based on wild collection [Bakalial et. al. 2011]. In recent time ornamental fishmarketing has been growing in faster way in different parts of the globe and many fish farmers as well asentrepreneurs involved in the trade. Improvement of air transport facility along with some other scientific inventions transformed this ornamental fish industry into a lucrative bio-trade industry in many countries including the India. The recent value of world trade for ornamental fish has been estimated to be about 4.5 billion US [Dutta et. al.2012]. In view of the paucity of knowledge an attempt has been made to study the taxonomy of the ornamental fishes available from upper stretches of the Bhima river.

The Bhima river and its tributaries like Indrayani, Mula, Mutha. etc flow through this region. Fig. 1. shows the study area. 


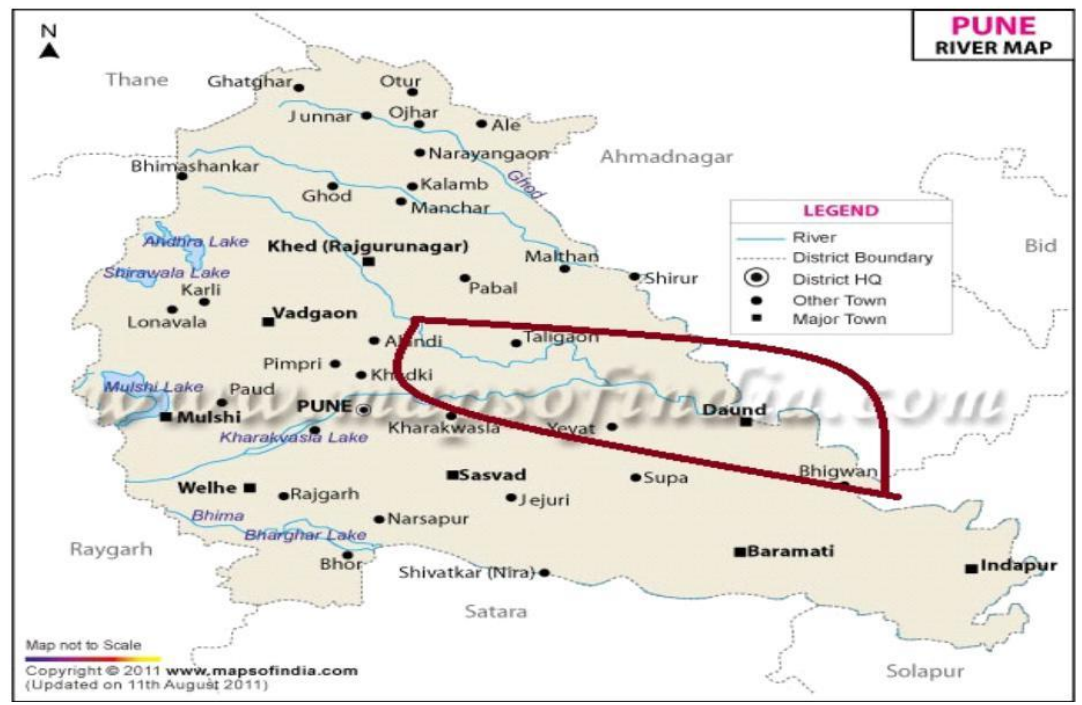

\section{Figure .1: Study area of Bhima river Eastern part for ornamental fishes.(2011-12)}

Material Methods

Specimens of fishes were collected from four tehsils of Pune district viz, Shirur, Daund, Haveli and Indapur. The fish samples were collected from seven sampling stations as S1-Tulapur, S2- Koregaon Bhima, S3-Pimprisandas, S4Walkisangam, S5-Daund, S6-Alegaon and S7-Siddhatek.

Fishes pertaining to the present study were collected from different landing centers, markets and also from various lentic and lotic systems of the region by

periodically visiting these places between August 2011 and June 2012. While selecting ornamental fishes not only the coloration of the species but also certain other unusual morphological characteristics such as bizarre shape, prolonged tail etc. are also considered. The collected fishes were preserved in 5 $\%$ formalin for further studies. The specimens were identified following[ Munshi and Srivastava (1988), Talwar and Jhingran (1991) and Biswas (1993)]. 


\section{Result and Discussion}

Table No.1:Ornmental fish species Showing abundance at Eastern part of Bhima river during the year 2011-12.

\begin{tabular}{|c|c|c|c|c|c|c|c|c|c|c|}
\hline Family & Name of the fish & $\begin{array}{l}\text { Feeding } \\
\text { habit }\end{array}$ & $\begin{array}{l}\mathrm{S} \\
1\end{array}$ & $\begin{array}{l}S \\
2\end{array}$ & $\begin{array}{l}S \\
3\end{array}$ & $\begin{array}{l}\mathrm{S} \\
4 \\
\end{array}$ & $\begin{array}{l}\mathrm{S} \\
5 \\
\end{array}$ & $\begin{array}{l} \\
6 \\
\end{array}$ & $\begin{array}{l}\mathrm{S} \\
7\end{array}$ & Abundance \\
\hline \multirow[t]{2}{*}{ 1.Notopteridae } & 1.Notopterus chitala & $\mathrm{SCF}$ & & & & + & + & + & & $\mathrm{C}$ \\
\hline & 2.N. notopterus & $\mathrm{SCF}$ & + & - & & + & - & _- & - & $\mathrm{C}$ \\
\hline \multirow[t]{12}{*}{ 2.Cyprinidae } & 3. Osteobrama cotio & $\mathrm{CF}$ & + & + & - & + & + & - & _- & $\mathrm{M}$ \\
\hline & 4. Osteobrama vigorsii & $\mathrm{CF}$ & & + & + & + & + & - & - & $\mathrm{C}$ \\
\hline & 5. Puntius chola & $\mathrm{BCF}$ & + & + & + & + & & & & $\mathrm{M}$ \\
\hline & 6.Puntius amphibious & $\mathrm{BCF}$ & & & & + & + & + & & A \\
\hline & 7.Puntius sarana sarana & $\overline{\mathrm{BCF}}$ & - & + & + & + & - & - & _. & $\mathrm{M}$ \\
\hline & 8. Puntius sophore & $\mathrm{BCF}$ & - & - & + & + & + & - & $=$ & $\mathrm{A}$ \\
\hline & 9.Puntius ticto & $\mathrm{BCF}$ & - & - & + & + & - & - & $=$ & $\mathrm{A}$ \\
\hline & 10. Puntius conchonius & $\mathrm{BCF}$ & + & + & _- & + & _ & _ & _ & $\mathrm{M}$ \\
\hline & 11. Rohtee ogilbii & $\mathrm{BCF}$ & _. & + & + & + & + & _ & _ & $\mathrm{C}$ \\
\hline & 12. Salmostoma acinaces & $\mathrm{SF}$ & _- & + & _- & _- & - & - & - & $\mathrm{C}$ \\
\hline & 13.Salmophasia balooki & $\mathrm{SF}$ & - & + & + & + & + & - & - & $\mathrm{C}$ \\
\hline & 14. Salmophasia bacaila & $\mathrm{SF}$ & + & + & & + & + & & & A \\
\hline \multirow[t]{6}{*}{ Family } & Name of the fish & $\begin{array}{l}\text { Feeding } \\
\text { habit }\end{array}$ & $\begin{array}{l}\mathrm{S} \\
1\end{array}$ & $\begin{array}{l}\mathrm{S} \\
2\end{array}$ & $\begin{array}{l}\mathrm{S} \\
3\end{array}$ & $\begin{array}{l}\mathrm{S} \\
4\end{array}$ & $\begin{array}{l} \\
5\end{array}$ & $\begin{array}{l}S \\
6\end{array}$ & $\begin{array}{l}\mathrm{S} \\
7\end{array}$ & Abundance \\
\hline & 15. Securicula gora & $\mathrm{BCF}$ & & + & & + & + & & & $\mathrm{M}$ \\
\hline & $\begin{array}{l}\text { 16.Amblypharyngo-don } \\
\text { mola }\end{array}$ & $\mathrm{SCBF}$ & + & + & + & + & + & + & - & $\mathrm{C}$ \\
\hline & 17. Garra mullya & SCF & + & + & + & + & - & _ & + & $\mathrm{M}$ \\
\hline & 18. Garra gotlya gotlya & $\overline{\mathrm{SCF}}$ & - & - & - & + & + & - & - & $\mathrm{M}$ \\
\hline & 19.Oreonectus evezardi & $\mathrm{BF}$ & - & - & + & - & - & - & - & $\mathrm{R}$ \\
\hline \multirow[t]{5}{*}{ 3.Siluridae } & 20. Ompak bimaculatus & $\mathrm{BCF}$ & + & $=$ & + & + & + & + & + & $\mathrm{C}$ \\
\hline & 21.Ompak pabda & $\mathrm{BCF}$ & _- & - & + & + & + & + & + & $\mathrm{M}$ \\
\hline & 22. Ompak malabaricus & $\overline{\mathrm{BCF}}$ & + & - & + & _- & _ & _ & - & $\mathrm{R}$ \\
\hline & 23.Ompak pabo & $\overline{\mathrm{BCF}}$ & + & - & _- & - & + & - & - & $\mathrm{M}$ \\
\hline & 24. Wallago attu & $\mathrm{BCF}$ & & & + & + & + & + & + & $\mathrm{R}$ \\
\hline \multirow[t]{3}{*}{ 4.Bagridae } & 25.Mystus bleekeri & $\mathrm{BF}$ & + & + & + & + & + & + & + & $\mathrm{C}$ \\
\hline & 26.Mystus cavasius & $\mathrm{BCF}$ & + & + & + & + & + & + & + & $\mathrm{C}$ \\
\hline & 27.Sperata aor & $\mathrm{BCF}$ & + & _- & _- & _- & 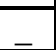 & + & + & $\mathrm{M}$ \\
\hline \multirow[t]{2}{*}{ 5.Claridae } & 28. Clarius batrachus & BSFV & + & + & + & 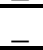 & 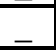 & + & + & $\mathrm{M}$ \\
\hline & 29. Clarius garipinus & BSFV & + & - & - & + & + & + & + & $\mathrm{M}$ \\
\hline 6.Heteropnustidae & 30.Heteropneustes fossilis & BSFV & + & + & + & + & + & + & + & A \\
\hline 7.Poeciilidae & 31.Gambusia affinis & SF & _- & - & + & + & - & - & _- & $\mathrm{M}$ \\
\hline 8.Gobiidae & 32.Glossogobius giuris & $\mathrm{BF}$ & + & - & + & + & + & + & + & $\mathrm{C}$ \\
\hline \multirow[t]{2}{*}{ 9.AmbassCidae } & 33. Chanda nama & SCF & - & - & + & + & + & - & - & $\mathrm{C}$ \\
\hline & 34.Parambassis ranga & $\overline{\mathrm{SCF}}$ & - & + & + & + & + & - & 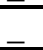 & $\mathrm{M}$ \\
\hline \multirow[t]{2}{*}{ 10. Channidae } & 35.Channa punctatus & $\mathrm{BCF}$ & + & + & + & + & + & + & + & $\mathrm{C}$ \\
\hline & 36.Channa maurilus & $\overline{\mathrm{BCF}}$ & + & + & + & + & + & + & + & $\mathrm{M}$ \\
\hline \multirow[t]{2}{*}{ 11.Mastacembelidae } & $\begin{array}{l}\text { 37.Mastacembelus } \\
\text { armatus }\end{array}$ & $\mathrm{BF}$ & + & + & + & + & + & + & + & $\mathrm{C}$ \\
\hline & $\begin{array}{l}\text { 38.Macrognathus } \\
\text { panaculus }\end{array}$ & $\mathrm{BF}$ & + & - & - & + & + & + & + & $\mathrm{M}$ \\
\hline
\end{tabular}

\# Abundance category : A- abundant, C-common, M- moderate, R- rare. 
* Feeding habit :BF-Bottom feeder, CF- Column feeder, SF- Surface feeder, SCF-Surface column feeder, BCF- Bottom column feeder, SCFV-Surface column feeder, BSFV- Bottom feeder surface water.

List of ornamental fishes recorded in Bhima river water along with their respective families, scientific names, local names, frequency of occurrence, feeding habit, prominent ornamental features and status are summarized in the Table:1. A total of 38 ornamental fish species belongs to 11, 19 families and genera respectively were recorded while family wise distribution pattern is depicted in the Figure: 2.

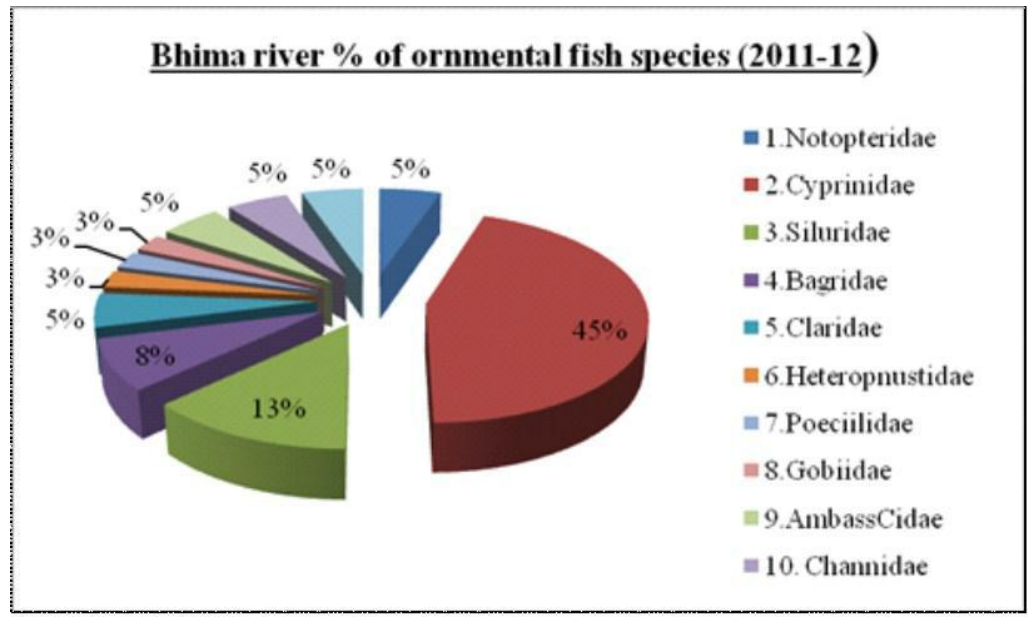

Figure: 2. Percentage of ornmental fish species in the eastern part of Bhima river (2011-12)

Out of 38 ornamental fish species $4(10.52 \%)$ species were abundant, $16(42.10 \%)$ species were moderate, 15 (39.47\%) species were common and $43(7.89 \%)$ species were rare in the water of Bhima river. Seven various types of feeding habit namely (1) Surface column feeder SCF (6species i.e. 15.78\%), (2) Surface feeder SF (4 species i.e. 10.52\%) (3) Bottom feeder BF (4 species i.e. 10.52\%), (4) Bottom column feeder BCF (17 species i.e. 44.73\%), (5) Surface column bottom feederSCFV (1 species i.e. 2.63\%) (6) Bottom feeder surface visitor BSFV(3 species i.e. 7.89\%) and (7) Column feeder (2species i.e.5.26\%). 


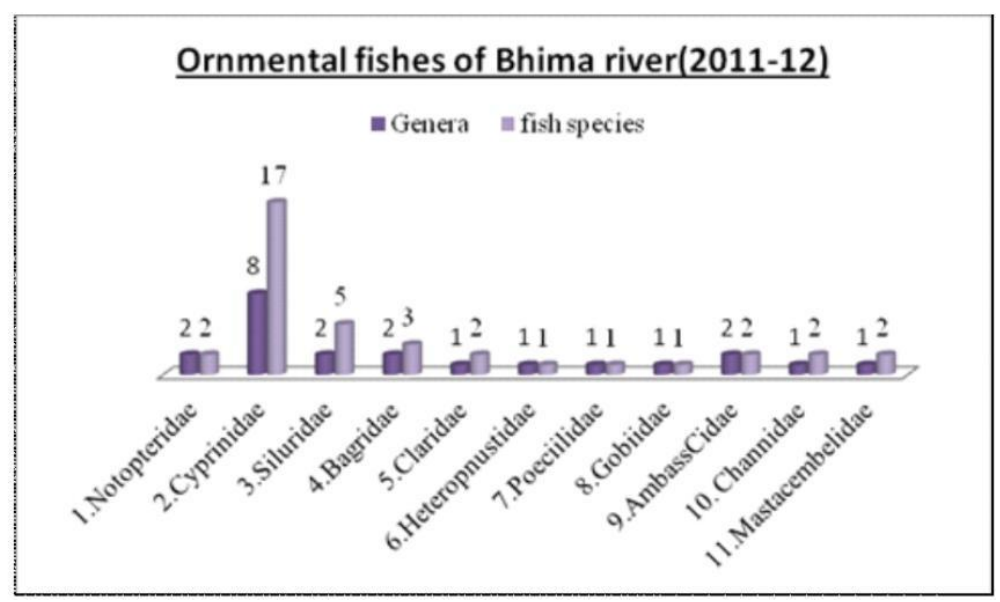

Figure: 3 Ornmental fishes under genera and species in the eastern part of Bhima river during year2011-12

\section{Conclusion}

Habitat conservation of the river, an ore of native fish species is to be imperative because, at present the river is in such a state that native fishes alone cannot withstand the fishing pressure due to collapse in native fish stock [Bakalial et. al. 2011]. Integrity of aquatic communities and ecosystems should be conserved by appropriate management techniques. In particular, efforts should be made to minimize the harmful effects of over-fishing in these water bodies. In this regard, the carrying capacity of aquatic environments should be well studied in order to eliminate the adverse effect on native fish fauna. The problem needs to be addressed with a view to find a long term solution in terms of sustainable income generation and conservation of the ecosystem symbiotically. Mass culture of ornmental fish has manifold advantages as it reduces pressure on the natural habitats, maintained ecological balance of our local environment by restoration of species; restoration of the diversity and make possible of the conservation of rare, endangered and endemic species [Hazarika et. al.2009]. Ornamental fish culture in captive condition and their trade still have not been well planned in the Western ghat region of India, a mega-biodiversity centre and a hotspot [Myers et.al. 2000]. Therefore, the 
government organizations and some NGOs should play imperative role to the same. Large scale ornamental fish production programmed with the help of mass culture is hoped to be the best measures for conservation of habitat and threatened species besides being creating substantial job opportunities for the locals.

\section{Refernces}

Bakalial B,, S. Borah and L.P. Hazarika, Ornamental fishes from hill stream channels of Subansiri drainage Books on Rivers and streams of North East India: Ecology, Biodiversity and Conservation, Akash Publishing House, New Delhi,India, 2011, pp.143-150

Biswas, S.P. 1993. Manual of Methods in Fish Biology. South Asian Publishers Pvt. Ltd., New Delhi, 157pp.

Biswas, S.P. 1996. Ecology of river islands of the Brahmaputra with special reference to fisheries. Annual Report. Submitted to Ministry of Environment \& Forests, Govt. Of India, 27pp.

Dutta N. N, S. Borah and Debojit Baruah "Potential Ornamental Ichthyofauna of Bordoibam Bilmukh Bird Sanctuary(IBA-site) and implication for conservation, North Eastern India" European Journal of Experimental Biology, 2012, 2 (5):1632-1638

Hazarika L.P, D. Baruah, B. Bakalial, S. Borah and R. Dutta, Procddeing of the National Seminar on "Agroforestry for Socio-Economic development of North Eastern Region, NERIST, Arunachal Preadesh,2009, 94-103

Jameson J. D. and P. Sonthanam, "Ornamental Fish Cul-ture. The National Symposium for Aquaculture for 2000 (AD)," Madurai Kamoraj University, India Press, Madu- rai, 1994, pp. 72-87.

Manna A K. and S. Banerjee, "Sexual Dimorphism in the Cyprinedontied Weed Fish Oryzias melartigma," Science \& Culture, Vol. 50, No. 4, 1984, p. 329. 
Munshi, J.S.D. and M.P. Srivastava 1988. Natural History of Fishes and Systematics of Fresh Water Fishes of India. Narendra Publishing House, Delhi.

Myers N, R.A., Mittermeier, C.G., Mittermeier, GAB da, Fonseca, and J. Kent. Nature, 2000,403: 853-855

Nagesh T. S, J. Barman and D. Jana, "Karyomor-phological Study of three Freshwater Ornamental Perches of West Bengal," Journal of Inland Fish Society India, Vol. 36, No. 2, 2004, pp. 45-48.

Pethiyagoda R, "Freshwater Fishes of Sri Lanka," Wild-life Heritage Trust, Sri Lanka, Colombo, 1991, p. 362.

Rajan M. R. and N. Karpagam, "Effect of Different Con- centrations of Vitamin c on Feed Utilization and Breeding of Certain Live, Breading Ornamental Fishes," Environ- ment and Ecology, Vol. 22, No. 1, 2004, pp. 31-37.

Roberts T. R, "Systematic Revision of the Old World Freshwater Fish Family Notopteridae," Ichthyological Exploration of Freshwater, Vol. 2, No. 4, 1992, pp. 361- 383.

Sarma S., B. K. Bhattacharjya, S. G. S. Zaildi and A. Landge, "Indigenous Ornamental Fish Biodiversity of Central Brahmaputra Valley Zone Assam," Journal of Inland Fisheries Society of India, Vol. 36, No. 1, 2004, pp. 29-35.

system of Assam, North east India: Potential for the aquarium fish trade and conservation issues in L. Kosyging eds.

Talwar, P. K. and A. G. Jhingran 1991. Fishes of India and Adjacent Countries. Vol. I \& IL Oxford \& IBH Publishing Co. Pvt. Ltd. New Delhi 